\title{
An institutional trust as a factor of youth civic engagement at local government
}

\author{
Elena Nikitina, Elena Vasileva*, and Tatiana Zerchaninova \\ Russian Presidential Academy of National Economy and Public Administration, March 8 Str., 66, \\ 620144 Ekaterinburg, Russia
}

\begin{abstract}
Trust in political institutions is the most important component of a legitimate state. Based on the authors' empirical research on the participation of Russian youth in local self-government, the article analyzes the trust in the municipal government in comparison with the level of civic engagement. The theoretical basis of the article is the institutional theory. According to it trust can be considered as an integral characteristic of the functioning of a political institution. To study the practice of youth participation in local self-government, the authors conducted an empirical sociological study in October-November 2020. The data collection method is a questionnaire survey of young Russian people aged 14-30 years $(n=2000$ people). The article argues that young people are characterized by a high level of declared civic engagement. However, the level of youth trust in local government remains low. The trust is associated with awareness of the activities at level: the lower the level of awareness of young people about the work of local authorities, the lower the level of trust in them.
\end{abstract}

\section{Introduction}

In recent decades, there has been a clear downward trend in the participation of young people in political processes, which is manifested, inter alia, in the low turnout of young people in elections and a decrease in the number of young people who are members of a political party. This is especially acute at the local level, leading to a decrease in the participation of young people in resolving issues of the local community, and, as a consequence, a decrease in civic activity, the formation of protest behavior.

In the scientific literature, the idea that citizens' trust in political institutions is declining has become widespread [1]. Characterizing the Russian situation, the authors come to the conclusion that Russian society is characterized by a low, but rather stable institutional trust. High level of trust extends primarily to institutions that have weak effect on the everyday life of Russians and which act as ceremonial symbols of the state [2]. In turn, the trust in local government remains low [3].

Trust in political institutions is the most important component of a legitimate state. Trust is also viewed as a characteristic of the Good Governance paradigm as an inherent property of "good" political systems, since even if trust does not necessarily intersect

\footnotetext{
* Corresponding author: vasilyeva-ekb@yandex.ru
} 
conceptually with legitimacy, institutional trust and social capital are the foundation of any political system.

This article analyzes the factors that predetermine the trust of Russian youth in local government from the standpoint of institutional theory.

\section{Literature review}

Current research in the field of trust and civic participation is devoted to applied aspects. E. Uslaner and M. Brown, considering the ratio of these categories, come to the conclusion that "trust plays an important role in the level of citizen participation in political decisionmaking, but, unlike the traditional approach, but according to their theory, the causal relationship extends from trust to participation " [4]. A number of other authors believe that "civic participation has a positive effect on institutional trust, only under the condition of high ethical behavior of employees and in the case of high quality public services" [5]. An analysis of the literature [6] allows us to conclude that the satisfaction of citizens with interaction with public authorities has a positive effect on the assessment of transparency and increases trust in local governments. At the same time, trust in local self-government bodies ensures higher civic engagement: trust in the government stimulates citizens to interact and encourages them to participate in various forms of local self-government. Consequently, the public's trust in local government bodies can be considered as an integral characteristic of the quality of the institutional environment of municipal government. Among the properties that institutions must possess in order to inspire trust, the authors name fairness, efficiency, competence, universality, separation of powers [7].

According to D. North, "the loss of trust in institutions makes their demise a selffulfilling prophecy" [8]. Russia is characterized by low trust in local self-government, which reflects its current image as ineffective in protecting the interests of individuals and groups, assisting in solving pressing social problems [9], and a lack of trust acts as one of the explanatory factors for the ineffectiveness of institutional reforms in Russia [2]. In this regard, the search for mechanisms that contribute to the growth of the level of trust between the governed and the managers in the context of interaction between local governments and authorities is becoming an urgent task.

\section{Materials and methods}

To study the practice of youth participation in local self-government, the authors conducted an empirical sociological study in October-November 2020. The data collection method is a questionnaire survey of young people aged $14-30$ years $(n=2000$ people) living in the Russian Federation. The research task was to analyze the practice of youth participation in local government in various forms. The processing of the empirical data results was carried out in SPSS Statistics 17.0/

\section{Research results}

As a result of the study, the respondents were asked to answer a set of questions dedicated to their level of civic engagement, as well as the degree of trust in local government bodies.

Discussing the values of civic participation of youth in the life of local self-government, there is a high level of declared civic engagement. More than half of the respondents consider themselves active citizens who are directly involved in various activities aimed at improving the life of the city (Table 1). 
Table 1. What is your civil position?

\begin{tabular}{|c|c|c|}
\hline & Variable & Valid \% \\
\hline 1 & Active & 26,5 \\
\hline 2 & Rather active & 40,1 \\
\hline 3 & Passive & 13,2 \\
\hline 4 & Rather passive & 11,7 \\
\hline 5 & Difficult to answer & 8,5 \\
\hline & Total & 100 \\
\hline
\end{tabular}

Analyzing the level of confidence of young people in local governments (local administration, city Duma), it is worth noting that the opinions of the respondents were almost equally divided: $15 \%$ of respondents do not completely trust the authorities, while only $9,2 \%$ fully trust (Table 2 ). In our opinion, the results obtained indicate a rather distrustful relationship with the authorities. At the same time, young people with a more active civic stance show more interest and trust in local authorities, which is confirmed by the results of two-dimensional contingency tables for the parameters "civic position" "level of trust in the authorities."

Table 2. Do you trust local governments?

\begin{tabular}{|c|c|c|}
\hline 1 & Variable & $\begin{array}{c}\text { Valid \% } \\
9,2\end{array}$ \\
\hline 2 & Rather trust & 31,8 \\
\hline 3 & Rather do not trust & 29,6 \\
\hline 4 & Do not trust & 15,0 \\
\hline \multirow[t]{2}{*}{5} & Difficult to answer & 14,4 \\
\hline & Total & 100 \\
\hline
\end{tabular}

In this study, age is a key parameter for analysis. Trust in local government differs significantly by age. Table 3 presents the results of the level of trust in local authorities depending on the age of the respondents (Table 3). The youngest age group of youth is characterized by higher trust. As can be seen from the presented table 3 , young people aged 14-17 show full confidence in the authorities. Young people aged 22-25 show complete distrust of the authorities $(23,3 \%)$, "I rather do not trust" $(32,1 \%)$ - young people aged 26 30.

Nevertheless, the number of "positive" assessments is less than half in all age groups, which allows us to conclude that young people do not trust local governments.

Table 3. Youth confidence in local self-government bodies, depending on the age of the respondents, $\%$

\begin{tabular}{|c|c|c|c|c|c|c|}
\hline Age & Totally trust & $\begin{array}{c}\text { Rather } \\
\text { trust }\end{array}$ & $\begin{array}{l}\text { Rather do } \\
\text { not trust }\end{array}$ & $\begin{array}{c}\text { Do not } \\
\text { trust }\end{array}$ & $\begin{array}{l}\text { Difficult to } \\
\text { answer }\end{array}$ & Total \\
\hline $14-17$ & 10,2 & 37,6 & 23,6 & 12,2 & 16,4 & 100,0 \\
\hline $18-21$ & 9,2 & 34,0 & 30,9 & 13,3 & 12,6 & 100,0 \\
\hline $22-25$ & 7,3 & 24,4 & 30,5 & 23,3 & 14,5 & 100,0 \\
\hline $26-30$ & 9,5 & 30,0 & 32,1 & 13,8 & 14,6 & 100,0 \\
\hline Total & 9,2 & 31,8 & 29,6 & 15,0 & 14,4 & 100,0 \\
\hline
\end{tabular}

The study of the confidence level of young people in local authorities also differentiates depending on the region of residence of the respondents. The most loyal to the local 
authorities in comparison with other answers were young people. People who living in the Volga Federal District $(15,5 \%)$ rather trust than do not trust authorities are respondents living in the Far East $(44,6 \%)$ and Central Federal Districts. The opposite situation is observed in the North Caucasian (45\%) and Ural (36\%) federal districts, where respondents rather do not trust the authorities. An interesting relationship was found as a result of pairwise comparisons of data on the parameters "degree of awareness of the activities of local authorities" - "level of trust in local authorities" (Table 4).

Table 4. The level of confidence of young people in local authorities, depending on the degree of awareness of their activities, valid \%

\begin{tabular}{|l|c|c|c|c|c|c|}
\hline \multicolumn{1}{|c|}{ Variable } & $\begin{array}{c}\text { Totally } \\
\text { trust } \\
\text { Fully informed }\end{array}$ & $\begin{array}{c}\text { Rather } \\
\text { trust }\end{array}$ & $\begin{array}{c}\text { Rather do } \\
\text { not trust }\end{array}$ & $\begin{array}{c}\text { Do not } \\
\text { trust }\end{array}$ & $\begin{array}{c}\text { Difficult } \\
\text { to answer }\end{array}$ & Total \\
\hline Rather informed than not & 39,8 & 29,6 & 14,5 & 10,2 & 5,9 & 100,0 \\
\hline Rather not informed & 6,9 & 45,4 & 28,1 & 10,0 & 9,7 & 100,0 \\
\hline Not informed & 4,4 & 27,9 & 39,2 & 13,9 & 14,5 & 100,0 \\
\hline difficult to answer & 8,6 & 16,1 & 29,3 & 32,5 & 13,6 & 100,0 \\
\hline Total & 2,9 & 19,7 & 11,7 & 15,3 & 50,4 & 100,0 \\
\hline
\end{tabular}

As a result of the analysis of the data presented in Table 4, it was revealed that young people who are fully informed about the activities of local bodies of local self-government expresses full confidence in them $(39,8 \%)$. The opposite situation: the less the youth is aware of the work of local authorities, the lower the level of trust in it $(32,5 \%)$. This conclusion, of course, should become the basis for the formation of an updated concept of informing citizens and, first of all, young people about the activities of local governments, taking into account the most preferred communication channels (Table 5).

Table 5. What sources of information do you trust more?

\begin{tabular}{|c|l|c|}
\hline \multicolumn{1}{|c|}{ Sources of information, variable } & Valid \% \\
\hline 1 & Newspapers, magazines & 17,5 \\
\hline 2 & Television, radio & 31,2 \\
\hline 3 & Information stands located in local governments & 24,4 \\
\hline 4 & Flyers, posters, announcements & 15,1 \\
\hline 5 & Internet (news feeds etc.) & 60,2 \\
\hline 6 & $\begin{array}{l}\text { Official website of local governments, their groups in social } \\
\text { networks }\end{array}$ & 39,4 \\
\hline 7 & YouTube, Telegram, messengers. & 35,8 \\
\hline 8 & Email & 6,1 \\
\hline 9 & Training sessions & 13,3 \\
\hline 10 & $\begin{array}{l}\text { Conversations, conversations with friends, relatives, work } \\
\text { colleagues, neighbors }\end{array}$ & 18,4 \\
\hline
\end{tabular}

Thus, the Internet, social networks and the website of local government bodies are reliable sources of information for Russian youth, so it is advisable to inform about the activities of government bodies through these channels.

\section{Conclusion}

The research was based on institutional theory, according to which individuals need institutions that they are able to understand, with which they have experience of working. 
In view of the lack of practice of interaction with local governments and a poor understanding of their activities, young people experience low trust to local governments, which is confirmed by the results of the study.

The results of the study showed that, despite the high level of civic engagement, trust in local governments remains low. Trust in local government differs significantly by age. The youngest age group of youth is characterized by higher trust. However, the total number of "positive" ratings is less than half in all age groups. To an even greater extent, trust depends on awareness of the activities of local authorities of local government: the less awareness of youth about the work of local authorities, the lower the level of trust in them.

\section{Acknowledgements}

The reported study was funded by RFBR and EISR according to the research project no. 20-011-31551.

\section{References}

1. P. Norris, ED Critical Citizens: Global Support for Democratic Governance (1999)

2. S.V. Mareeva, Terra Ecomonicus, 3 (2015)

3. V.V. Volchik, Terra Ecomonicus, 2 (2012)

4. E.M. Uslaner, M. Brown, American Politics Research, 33 (2005)

5. X. Wang, M. Wan Wart, Public Administration Review, 67 (2007)

6. S. Scherer, M.A. Wimmer, EDS Lecture Notes in Computer Science, 8654 (2014)

7. D.F. Terin, Sociological journal, 2 (2018)

8. P. N. Rybchak, Management consulting, 9 (2015)

9. O.B. Molodov, Power, 11 (2016) 